\title{
SZERVEZETI KÉPZÉSEK GYAKORLATA MAGYARORSZÁGON A NEMZETKÖZI ADATOK TÜKRÉBEN
}

Az eltérő szervezeti környezetben (vállalatok és intézmények) folyó képzések és különösen a tréningek hatékonyságának értékelése régóta fennálló problémakör, amelyre a vezetők és HR-szakemberek hosszú idő óta keresik a megfelelő eszközöket és módszereket. A szerzők cikkükben bemutatják a 2016-ban több mint 400 magyarországi szervezet közreműködésével (vállalatnál és intézménynél) végzett felmérésük tapasztalatait, majd ezeket összevetik a 2004-2005, 2008-2010 és 2015-16. évben folytatott, nemzetközi, úgynevezett Cranet-felmérés során kapott válaszokkal. Empirikus vizsgálatuk alapján következtetéseket vonnak le a magyarországi szervezeteknél folyó képzések és tréningek jellemzőiről és az ott alkalmazott hatékonyságmérési módszerekről.*

Kulcsszavak: HRM, tréning, tréninghatékonyság, Cranet-felmérés

A Nobel-díjas Schultz (1993) az emberi tőkének, illetve az abban megtestesült tudásnak a gazdasági növekedésben betöltött szerepét hangsúlyozza. Következtetése, hogy az emberi tökeberuházások magasabb növekedési rátát eredményeznek a fizikai tőkéhez képest, mivel az emberek képzésébe, fejlesztésébe történő beruházás növeli az ember munkavégző, értékteremtő képességét. A versenyelöny alapvető meghatározója a cég tevékenységében és outputjaiban manifesztálódott emberi tudás. A tartós versenyelöny fenntartásában nemcsak nélkülözhetetlen, hanem stratégiai kérdéssé váltak az olyan humánerőforrás-tevékenységek, mint a megfelelő munkaerő kiválasztása vagy a meglévők képzése, fejlesztése. „Az igazi és versenyelőnyt jelentő tudás és annak megosztása a gyorsan változó környezetben, a kiszámíthatatlanság miatt az egyik legfontosabb szervezeti potenciállá válik, hiszen ez az alkalmazkodóképességet növeli" (Poór, 2013, p. 138.). Kotler és Caslione (2011, p. 67.) összeköti a tökepiac diktálta kemény követelményeket az emberi tudással, mint gazdasági tényezővel, amikor azt mondja, hogy azok a cégek, amelyek ,nem értik meg a képzés és fejlesztés értékét, végül a részvényesek értékeiből faragnak le".

$\mathrm{Az}$ emberi erőforrások fejlesztése (másképpen személyzetfejlesztés) egy folyamatos tevékenységsorozat, amely szervezett tanulást jelent abból a célból, hogy az egyént képessé tegye saját viselkedésének megváltoztatására a cég stratégiájának függvényében.
Az emberi erőforrások fejlesztéséhez mindenekelőtt a szervezeten belüli fejlesztési igényeket kell megismerni és meghatározni. Az emberi erőforrások fejlesztési szükségleteinek meghatározásához azokból a változásokból célszerü kiindulni, amelyek a vállalatok üzleti környezetében tendenciaszerüen megfigyelhetők. Ezek szervezeti és egyéni szintü megjelenítése képezheti a konkrét alapot a vállalati igények meghatározásához. A képzés-oktatás elsődleges lehetőséget kínál az összes alkalmazott tudásbázisának bővítésére, sok munkáltató azonban költségesnek tartja ezeket a fejlesztési lehetőségeket. Az alkalmazottak szintén sokszor feleslegesnek tartják az ilyen programokon való részvételt, mivel az ezek miatti kiesés késleltetheti az általuk végzett munka vagy felügyelt projektek befejezését (Price, 2015). Az előbb említett lehetséges nehézségek ellenére a képzés és a fejlesztés a vállalat egészének és az egyéni munkavállalóknak is olyan előnyöket biztosít, amelyek költség- és időráfordítást érdemelnek a specifikus, rövid távú képességfejlesztés valamint a hosszú távú fejlődés biztosítása érdekében (Gilmore - Williams, 2013; Gomez et al., 2016).

Bartscher és Nissan (2017) úgy vélik, hogy az emberierőforrás-menedzsment területének - beleértve a témánk szempontjából kiemelt fontosságú képzést is - vizsgálata számos módon történhet. A gazdasági vállalkozások előszeretettel támaszkodnak egy vagy több szervezet gyakorlatát összehasonlító benchmarking vizsgálatokra. Cikkünk is alapvetően ezt a logikát követi: a hazánk-

*Köszönetnyilvánítás

A cikk szerzői külön köszönettel tartoznak a Cranet-hálózat magyarországi (PTE KTK) és más országokbeli tagjainak, hogy publikációnkban használhattuk az ő általuk gyüjtött és rendszerezett adatokat. 
ban elvégzett empirikus kutatás tükrében vizsgáljuk e területre jellemző tendenciákat és összevetjük a nemzetközi Cranet ${ }^{1}$-hálózat HR-kutatásainak adataival (2011 és 2017).

\section{A szervezeti képzések}

\section{Általános jellemzők}

A XXI. század a változások korát hozta el. Ahhoz, hogy meg tudjunk felelni ezeknek a változásoknak, meg kell tanulnunk alkalmazkodni a mindennapokhoz. Ennek egyik - s talán megkerülhetetlen eszköze - maga a tanulás. A felnőttkori tanulás pozitívumai közé sorolják gazdasági szempontból egyebek mellett a versenyképesség növekedését vagy a foglalkoztatottsági ráta javulását, míg az egyén életében a tanulás velejárója lehet a munkaerő-piaci helyzet kedvezőbbé válása és az ezzel együtt járó életszínvonal emelkedése is. E pozitívumok ellenére a hazai felnött korú lakosság mindössze $9 \%$-a vesz részt valamilyen képzésen, és így jelentős lemaradást mutat az EU 36\%-os átlagától (KSH, 2014).

A tanuláson belül megkülönböztetjük a formális, nem formális és az informális formákat, amelyek leginkább a tanulás környezetét, mintsem annak tartalmát határozzák meg. A nem formális tanulás egyik alapvető helyszíne maga a munkahely, ahol a tudás Boutellier és társai kutatásai alapján (idézi Berde - Móré, 2014) - négyféle módon szerezhető meg:

- tudás a szocializáció által (a vállalati kultúra megismerése által jön létre),

- tudás a tapasztalás által (a folyamatok megfigyelése útján és a szervezeti rutinnal jön létre),

- tudás a dokumentáció által (a szervezetben fellelhető írásos anyagok tartalmazzák),

- tudás a termékben (az alkotás útján létrejövő, már értékesíthető tudás).

Vámosi (2005, p. 301.) szerint a képzés ,, az emberi erőforrás fejlesztésének egyik eszköze - a dolgozók szakismereteinek bövitésével és a munkafeltételek állandóan változó követelményeinek való minél jobb megfeleléssel foglalkozik. Uj ismeretek biztositásával hozzásegitheti a dolgozókat további hatás- és munkakörök ellátásához, újabb szakmák elsajátitásához.” Goldstein és Ford (2002) megközelítése ezzel szemben inkább teljesítménycentrikus: szerintük a képzés az egyik legelterjedtebb módszer az egyéni teljesítőképesség fokozására, valamint a munkateljesítmény élénkítésére munkahelyi környezetben. Dessler a képzést úgy határozza meg (idézi Farjad, 2012), mint egy folyamatos tevékenységet, amely során különböző módszerek segítségével meglévő és új szolgáltatásokat nyújt az alkalmazottak számára, amelyek révén olyan készségek alakulhatnak ki vagy mélyülhetnek el, amelyekre a munka elvégzéséhez szükségük van, vagy lesz.
Az angol-amerikai terminológiában markánsan elkülönül a képzés és fejlesztés fogalma:

- a képzés, továbbképzés (Training) kifejezés alatt általában az alacsonyabb szintű és képzettségű munkavállalókra irányuló tevékenységet értik, amelynek célja a dolgozói hatékonyság növelése,

- a fejlesztés (Development) főleg a menedzserek és a szakemberek képességfejlesztését jelenti az angolszász területeken (Torrington et al., 2014).

Ezzel szemben a magyar szakirodalomban a tréninget gyakran a továbbképzés szinonimájaként használják, számos szerző ugyanakkor egy speciális képzési formát ért alatta. A széles körben elfogadott magyar terminológia szerint tehát a képzések egy speciális csoportját jelentik a tréningek. Légrádiné (2006, p. 61.) szerint a tréning egy „olyan, alapvetően készségfejlesztésre irányuló, csoportos fejlesztö módszer, amelyen a résztvevők személyes tapasztalatokat szereznek, a tapasztalat, tanulás révén új ismeretekhez jutnak önmagukról, másokról, különbözö helyzetekhez való viszonyulásaikról. Ehhez eszközként különféle játékokat, szituációs és szerepgyakorlatokat alkalmaznak a tréningek vezetöi, amelyeket feldolgoznak, a résztvevők egymásnak visszajelzéseket adnak, müködnek a csoportdinamika törvényszerüségei, és ezáltal fejlödnek a résztvevők szociális és interperszonális készségei”. A tréning céljai ezek alapján tehát nem a szakmai tudás bővítése, hanem inkább a meglévő ismeretek komplexebbé tétele, az új - tapasztalatokra épülő - készségek tudatosítása. Fontos kiemelni azt is, hogy a tréningeken föleg a munkahelyen hasznosítandó/hasznosítható kompetenciák fejlesztése a cél, ezek azonban olyan tudáshoz segítik hozzá a részvevőket, amelyet a mindennapi - magánéletbeli - helyzetekre is jól lehet adaptálni. Fel kell hívnunk a figyelmet arra, hogy míg a magyar szakirodalomban sokan tréning alatt kizárólagosan ezt a képzési formát értik, addig az angol szakirodalomban a tréning, mint képzési forma ettől eltérő értelmezésű, ami gyakran okoz terminológiai, fogalmi zavart, és egyáltalán nem meglepő, hogy sokan nehezen tudnak ezek között eligazodni. Amennyiben a képzéseket tovább differenciáljuk, a munkahelyi képzéseken belül megkülönböztethetjük a munkavégzés közbeni, házon belüli (on the job), vagy a munkavégzéstől elváló, külső (off the job) képzési formákat (Bokor et al., 2007).

Maticsákné (2012) a munkahelyi képzések tartalma alapján megkülönböztet beillesztő programokat, készségfejlesztő programokat, szakmai képzéseket, valamint vezetőképzést és karrierprogramokat (Vaszari, 2016). A munkahelyi képzések a kompetenciafejlesztés által olyan szervezeti célok megvalósításához is hozzájárulnak, mint például a minőség javítása, a termelékenység növekedése, az új technológia bevezetésére való felkészülés, a szervezeti rugalmasság növelése, a munkahelyi elégedettség növelése, vagy a szervezeti kultúra átalakítása. Annak

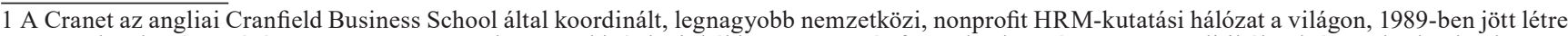
az ILO kezdeményezésére. A Cranet survey a legnagyobb és leginkább reprezentatív független kutatása a HRM-politikáknak és gyakorlatoknak, szerte a világon (Brewster et al., 2010). Az eredetileg öt nyugat-európai ország egyetemeit, illetve kutatóit tömörítő hálózat tevékenysége az ezredfordulóra globálissá vált napjainkra mintegy 40 ország kutatóit fogja össze, és a HRM-gyakorlatok nemzetközi alakulásának vizsgálatában kiemelkedő szerepet tölt be (Kovács - Karoliny, 2015).
} 
ellenére, hogy ismert a képzések pozitív hatása a szervezetek és az egyén vonatkozásában is, a Központi Statisztikai Hivatal adatai szerint 2015-ben mindössze a vállalkozások 44\%-ánál volt lehetőségük az alkalmazottaknak olyan képzése(ke)n részt venni, amelyet a cég valamilyen módon támogatott. A hivatalos adatok szerint a vállalkozások mérete mellett a fö tevékenység is jelentősen befolyásolja képzési aktivitásukat. „2015-ben a villamos energia-, gáz-, gőzellátás, légkondicionálás gazdasági ágban volt a legmagasabb, 85\% a képzéseket támogató cégek aránya, ezt a pénzügyi vállalkozások követték 77\%-os, majd az információ, kommunikáció, illetve a vizellátás, szenynyvizgyüjtés, -kezelés, hulladékgazdálkodási ágban tevékenykedők $60 \%$ feletti értékkel. A legalacsonyabb képzési arány a szálláshely-szolgáltatás, vendéglátás területén tevékenykedo" vállalkozásoknál mutatkozott, 25\%-kal" (Munkahelyi képzések, 2015).

\section{Vállalatok képzésről alkotott felfogásai}

A tudás és a tudást birtokló ember a szervezetek hosszú távú túlélésének fó letéteményesévé vált. Az emberek szaktudására, munkavégző, értékteremtő képességére úgy is tekinthetünk, mint a szervezetek számára rendelkezésre álló emberi (humán) tőkére. Az emberi tudás hatékony menedzselése lehetővé teheti a vállalatok számára, hogy az alkalmazottak tudását és készségeit optimálisan használják fel, miközben olyan humánerőforrás-menedzsment modelleket fejlesztenek, amelyek a környezet szükségleteihez igazodnak, mindezzel hozzájárulva a javuló szervezeti teljesítményhez (Sánchez et al., 2015; Csillag et al., 2018).

Farjad és munkatársai (2012) a szervezeti képzésekkel kapcsolatos kutatásaik eredményei alapján az alábbi főbb megállapításokat tették:

- az állandó - és egyre éleződő - versenyben a vállalatok az emberi erőforrást és tudást a teljesítményfokozására összpontosítják,

- a képzés hatását nem mindig vagy nehezen lehet a gazdasági paraméterek növekedésében lemérni, amit csak erősít, hogy a képzésen részt vett munkavállalók többlettudásának hatása nem közvetlenül a termelékenység szintjén jelenik meg,

- a vállalatok képzési kötelezettségét nem írja elő jogszabály, így a munkavállalók fejlesztését a cégek nem tekintik kötelező érvényünek,

- a képzésekre időt és költséget kell fordítani, így ha egy szervezet nem prosperál, akkor a képzési kiadások csökkentése az első lépések egyike.

A hatékonyabb képzések megkezdéséhez a szervezeteknek meg kell vizsgálniuk, hogy a képzési és fejlesztési rendszer hogyan müködik, és hogyan lehet összhangba hozni a szervezet stratégiájával. Az elmúlt időszak tendenciái alapján az alkalmazotti képzés azért válik egyre fontosabbá a szervezetek számára, mert felismerték, hogy ezzel egyszerre lehet javítani a szolgáltatások minőségén, csökkenteni a munkaerőköltségeket, valamint növelni a termelékenységet és a nyereséget egyaránt. Ezek ellenére az is igaz, hogy csak akkor tekintenek értékhordozóként e képzésekre a szervezetek, ha valamilyen módon az ott megtanultak átültethetők a teljesítménybe, vagy megjelennek a profitban. Ezért is van az, hogy a legtöbb szervezet azért bizonytalan a képzés-fejlesztés hasznosságában, mert nem áll rendelkezésre az azt megfelelően értékelö, mérő rendszer (Bramley - Kitson, 1994).

\section{A szervezeti képzések hatékonyságának mérési lehetőségei}

A szervezeti képzések tervezésénél, szervezésénél több olyan kérdésre érdemes odafigyelni, melyek befolyásolhatják azok eredményességét. Elsődleges kérdések között szerepel a trénerek, képzők kiválasztása. Ezek mellett elengedhetetlen a konkrét célok kitüzése. Ez a momentum döntő lehet, hiszen csak a konkrét célok elérését vagy el nem érését lehet mérni, s belölük megfelelö következtetéseket levonni. Ezeken túl figyelembe kell venni a célcsoport összetételét is, hiszen hozzájuk kell igazítani a képzés tárgyát, tartalmát. Ha munkahelyi képzésről van szó, akkor talán a helyszín - amely ugyan nem mellékes kérdése egyértelműnek tűnhet. Ekkor inkább a „mikor?” kérdésének megválaszolása okozhat nehézséget, hiszen a munkatársak időbeosztásának összehangolása sokszor áthidalhatatlan akadályokba ütközik (Juhász, 2009). Talán még jelentősebb a „miből” kérdésének megválaszolása, ami természetesen a cég nagyságától, anyagi helyzetétől, jövőbeli terveitől is függ.

Mindezek megválaszolása mellett az adott képzés hatékonyágához más - cégen belüli - tényezők is hozzájárulnak. Ahhoz, hogy egy képzés eredményes legyen vállalati szinten, elsősorban a vezetők elköteleződése és támogatása szükséges. Ehhez azonban elengedhetetlen maguknak a vezetőknek a képzése is. Az egyén motivációja, tudása, illetve képessége nagy befolyással van a vállalat munkateljesítményére. Tehát a munkahelyi képzésekre úgy kell tekintenünk, mint a szervezetben zajló fejlesztési folyamatok egy módszerére, amely mindig egy nagyobb szervezeti cél szolgálatában áll, adott szervezetfejlesztési cél megvalósulását támogatja.

Az egyén és a szervezet megítélésében döntő jelentőségü az eredményesség faktora. Amíg egy termelő szervezetnél az elért eredményeket ki lehet számolni, hiszen a profit, vagy a termelt áru mennyisége egy jól számszerüsíthető tény, addig egy olyan tevékenység eredményességét nehéz meghatározni, ahol egyes személyek vagy csoportok kompetenciáinak, vagy éppen attitüdjeinek (ki)fejlesztése a cél. Ugyanis a személyiség, vagy éppen a közösség fejlődésének megvan az az egyedisége, hogy azt nem lehet csupán egy komponensre visszavezetni.

A szervezeti képzések értékelésénél kétféle megközelítési módot különböztetünk meg. A kvantitatív szemléletmód szerint az egyes képzések eredményességét is számszerüsíteni lehet. Itt elsősorban a ráfordított összeg és a képzés utáni többlettudás mértékét hasonlítják össze. A kvalitatív megközelítés inkább a részvevők szubjektív véleményére és elégedettségére épít. Mindkét megközelí- 
tési módnak van létjogosultsága a tréningek értékelésénél, hiszen különböző - és a tréning sikerességének megítélésében szerepet játszó - kérdésekre tudják megadni válaszaikat (Gregor - Pallai, 2016).

Az emberi erőforrás növekvő szerepe kikényszeríti a kontrollingmódszerek e számokkal nehezen jellemezhető területen való alkalmazását. A humánkontrolling vállalati megjelenésében szerepe van a tudásalapú gazdaság elterjedésének, a professzionalizálódás előtérbe kerülésének, hiszen segíti a költségérzékeny emberierőforrás-gazdálkodás megvalósítását, és lehetővé teszi a foglalkoztatás gyenge pontjainak a feltárását, valamint a vezetői döntések megalapozását. Müködése során maga generálja a szükséges változtatásokat (Ambrus - Lengyel, 2006).

A képzési ciklus (1. ábra), valamint általában a képzések szisztematikus modellje számos hasonlóságot mutat a kontrolling kör elemeivel.

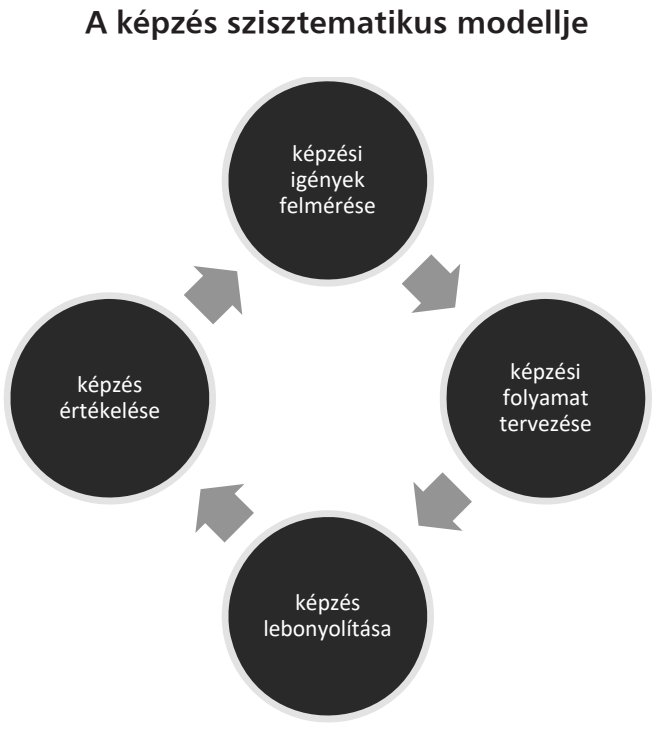

Forrás: a szerzők saját szerkesztése

Gyakori jelenség az, hogy a szervezetek az értékelésnél gyakran csak a képzés mennyiségére és nem a minőségére összpontosítanak. A képzés hatékonyságának megállapítása érdekében egy külön képzést érdemes szervezni. A szervezet ezután képes lesz pontosabban meggyőződni arról, hogy az elvégzett képzés hatékony volt-e. A képzés csak akkor válik hatékonnyá, ha a szerzett készségek és ismeretek megjelennek a teljesítményben, végső soron pedig a profitban.

\section{Hatékonyságmérési módszerek}

\section{Kirkpatrick modell}

A képzések értékelésének nemzetközi gyakorlatában a legismertebb módszertani modell Kirkpatrick (1998) nevéhez füződik, s a következő szinteket különbözteti meg:

1. A reakciók szintje, ahol a résztvevők (és érintettek) véleményét elemzik, vagyis azt, hogy milyen hatást váltott ki bennük a tréning. A módszer gyengeségei között említhető, hogy a résztvevők az adott képzést csak saját elvárásaikkal tudják összevetni, és a szubjektivitás „kockázata” is felmerül, hiszen egy rokonszenves trénert jobbnak értékelnek, továbbá az értékelés szintje nem garantálja, hogy a résztvevők új készségeket tanultak meg, vagy azokat a munkában használni is fogják. Kirkpatrick szerint minden programot legalább ezen a szinten kell értékelni ahhoz, hogy a későbbi képzési program igazodjon a szervezet igényeihez.

2. A tanulási hatás szintje, ahol rövid távú hatásként azt vizsgálhatják, hogy mennyiben változott a résztvevők tudása, készsége és attitüdje a tréning alatt. Ha ennek a szintnek a hosszú távú eredményét kívánjuk feltérképezni, akkor egy longitudinális vizsgálatot szükséges végeznünk a résztvevőkkel. Az előzetes tudást mérö eszköz használata révén kapott eredmények összevethetők a képzés utáni tudás/képesség mérésére kifejlesztett eszköz értékeivel. A két eredmény közötti értékváltozást tulajdoníthatjuk a képzés sikerességének.

3. A viselkedési hatás szintje mutatja, hogy mennyiben változott a résztvevők viselkedése a tréning következtében.

4. A szervezeti hatás szintje, ahol pedig azt vizsgálják, hogy mennyiben javult a szervezeti müködés a tréning következtében.

A harmadik és a negyedik szinten már a képzés viselkedési és szervezeti hatását lehet értékelni mely akkor lehetséges, ha az értékelők a képzési program előtt és után is kapcsolatban vannak a résztvevőkkel és az őket foglalkoztató szervezetekkel, és képesek a hatást tisztán mérni. Itt érdemes az interjú vagy a megfigyelés módszerét használni.

Egy amerikai kimutatás szerint az amerikai vállalatoknál az adott időszakban lezajlott tréningek $100 \%$-át értékelik az első szinten, $50 \%$-át a második, 30\%-át a harmadik, $20 \%$-át a negyedik, és $10 \%$-át az ötödik szinten (Dobos, 2009). Gősi (2007) szerint a hazai vállalkozásaink viszont legfeljebb a harmadik szintig értékelik képzéseiket. Ez azért is fontos kérdés lehet, mert az ASTD (American Society for Traning and Development) 2003-as kutatása szerint - közreadja Szalai (2009) - a képzésekre költött összeg 3,5-szörös megtérülést mutat éves szinten.

\section{Alkalmazási és továbbfejlesztési tapasztalatok}

A modellt számos területen adaptálták az elmúlt időszakban: a felsőoktatási tanulási eredmények értékelésére (Praslova, 2010; Rajeev et al., 2009) éppúgy használják, mint a tanárképzés (Shankar, 2007), és az orvosi képzések (Roos et al., 2014; Dunne et al., 2015) esetében, de akár olyan szakmai képzések hatékonyságának mérésére is alkalmazzák, mint a légiközlekedéshez kapcsolódó személyzetfejlesztés (Samad, 2014; Ford et al., 2014; Olšovská et al., 2016).

A Kirkpatrick-modellt fejlesztette tovább Philips, aki már a kvantitatív megközelítési módszer egyik legjelentősebb képviselője. Ö is hozzájárult az ún. ROI (Return 
On Investment) rendszer - ma ismert - kialakításához. A Phillips-modell a korábbi Kirkpatrick-elméletből származik, és attól abban tér el, hogy itt már egy ötödik szintet is meghatároznak. Ezen a szinten a befektetés megtérülésének mértékét mérhetjük. A ROI kiszámításához a 4. szintủ értékelésben összegyüjtött adatokat át kell alakítani financiális egységekre. Ehhez értéket kell meghatározni a képzési program által érintett minden fejlesztési egységre. Az értékelés - Philips (2003) szerint - egy szisztematikus folyamat, amely során egy tevékenység vagy folyamat értékét és jelentését határozzuk meg.

A képzés pénzügyi megtérülése megjelenhet az adott szervezet termelékenységének, árbevételének növekedésében, szolgáltatásainak javulásában, a nyereség növekedésében, vagy a költségek csökkenésében is. A pénzügyi megtérülést az alábbi ún. befektetési hozam képlettel határozhatjuk meg:

\section{a képzés eredmény - képzés összes költsége x100 a képzés összes költsége}

Minél nagyobb az arányszám, annál nagyobb mértékben térül meg az adott képzésre fordított költség.

Tehát összevetik a program pénzügyi eredményét, a program pénzügyi költségével, amelyet majd százalékban fejeznek ki. Lényeges figyelmeztetésként szükséges megjegyezni, hogy az 5. szintü értékelést csak abban az esetben lehet csak elvégezni, ha az előző négy szinten már megtörtént a képzés értékelése és az ott kapott adatokat az 5. szint számításainál figyelembe tudják venni.

A haszon-költség arány (BCR) is egy mutatószám a program értékelésénél:

\section{a képzés összes haszna}

a képzés összes költsége

Philips (2003) egy további kulcsfogalmat is bevezetett elméletébe: az izolálást. Ezzel próbálja meg elkülöníteni a képzés szervezetre vonatkozó hatásait más tényezőktől. Szerinte vannak ugyanis olyan eredmények, melyeket nehéz pénzügyi szinten kimutatni. Ilyen például a hasznosság érzése, vagy a stresszkezelési képesség, dolgozói elkötelezettség, panaszcsökkenés vagy a konfliktuskezelési módszerek alkalmazása. Szerinte egy vállalat, ha egy képzési programot akar végrehajtani, létre kell hoznia egy olyan - több láncból álló - rendszert, ahol az elégedettség mérésétől kezdve szisztematikusan lehet nyomon követni a tréning hatékonyságát. Hiszen ha a méréseket nem minden szinten végezzük, akkor végül nehéz lesz megállapítani, hogy az elért üzleti eredményeket ténylegesen milyen szinten és mik okoz(hat)ták. Másrészről, ha a vizsgálat negatív (vagyis a meg nem térülés) eredményét hozza magával akkor meg lehet nézni, hogy hol történt elakadás. Lehet, hogy a résztvevők nem tudták elsajátítani a tréning céljaiban szereplö képességeket, vagy nem tudták azokat sikeresen alkalmazni. Ha minden szinten „,mérünk”, akkor „lokalizálni” lehet a problémát, így sikeresen kereshet a szervezet erre hatékony megoldásokat. Az egyik legfontosabb a negyedik szint hatékonyságának mérése, hiszen az rávilágíthat az üzleti intézkedések miértjeire. Ezen a szinten a kimenet, a minőség, a költségek és az idő mérőszámai lehetnek döntőek. Philips megjegyzi azt is, hogy fontos túllátni a negyedik szint üzleti eredményein, még akkor is, ha a képzés nem hozott jelentős eredményeket üzleti értelemben.

Az elmúlt időszakban kutatások indultak (Moldovan, 2016) a Kirkpatrick-modell további fejlesztésére: a továbbgondolt rendszer alapvetően az egyes értékelési szintekhez társít célokat a PDCA-ciklus mentén. A modell előnye, hogy segít feltárni a tréningek hatékonyságát befolyásoló tényezőket.

$\mathrm{Az}$ áttekintés végén szólnunk kell arról is, hogy e hatékonyságmérések milyen csapdákat jelentenek a kutatás szempontjából. Egyrészt az alapvető nehézséget az okozza, hogy e képzések eredményességét csak utánkövetéses vizsgálatok által lehet kimutatni, ami minden esetben plusz idő, energia és anyagi ráfordítással jár. Másrészt a képzéseken zajló érzelmi folyamatok hatásai elfedhetik azok tényleges eredményét. A környezet is befolyásolja a hatékonyságot, hiszen ha a képzés a munkahelyen valósul meg, az a résztvevők számára frusztráló is lehet, így kihathat a tanulás folyamatára is.

\section{Empirikus vizsgálat}

\section{Kutatási módszer}

Vizsgálatunk alapvetően deduktív és magyarázó jellegü kutatásnak tekinthető, ami azt jelenti ebben az esetben, hogy a szervezetekben folyó képzésekre vonatkozóan „tendenciaszerü összefüggéseket” próbáltunk megállapítani (Héra - Ligeti, 2005, p. 46.). Jelen kutatásunkban szakirodalmi hivatkozások és a korábban már jelzett Cranet (2011 és 2017) nemzetközi kutatási hálózat keretében megszerzett, továbbá más kutatási tapasztalataink alapján (Karoliny - Poór, 2017; Poór, 2013) felgyülemlett információk alapján a témával kapcsolatban hipotéziseket fogalmaztunk meg.

Az említett Cranet nemzetközi HRM-kutatási hálózat képviselői által követett irányzat, amelynek logikájára épül a mostani kutatásunk is, a komparatív HRM-kutatások megközelítésén alapul. Ennek az elméleti alapját képező kontextuális kutatási paradigma - amely alapvetően különbözik a HRM-kutatásokban korábban elterjedt, univerzalista (best practice) megközelítésektől - az ún. szituatív, good practice kapcsolatok megközelítésén alapul. Ennek értelmében a szervezeti teljesítménnyel való kapcsolat kevésbé fontos, mint az, hogy mi okozza a vizsgált szervezeti képzések gyakorlatában a különbözö szervezeti és környezeti feltételek esetében mutatkozó különbözőségeket (Brewster, 1999, 2007). Az irányzat képviselői nem foglalkoznak a priori elméletek tesztelésével, hanem az adatokban rejlő mintázatokat keresve azt kutatják, hogy mi az, ami a HR-gyakorlatokat - adott kontextusban - egyedivé teszi. Ehhez elsősorban egyszerü, leíró statisztikai módszereket használnak (Martín - Alcázar et al., 2005).

Kutatásunkban tehát a komparatív HR-kutatások szemléletéből kiindulva a kontextuális kutatási paradig- 
mának megfelelően a képzés-fejlesztési gyakorlatokat a rájuk befolyást gyakorló sajátos környezeti és szervezeti kontextusba beágyazottan, elsősorban leíró statisztikai módszerekkel vizsgáljuk. Ezt a hipotézisek igazolása érdekében kiegészítjük erősebb statisztikai módszerek alkalmazásával is.

A különféle szervezeteknél (vállalatok és intézmények) folyó képzések és tréningek hatékonyságának az értékelése olyan régóta meg nem oldott problémakör, amelyre a vezetők és HR-szakemberek hosszú idő óta keresik a hatékony eszközöket és módszereket. A nemzetközi kutatások ${ }^{2}$ ugyanakkor azt mutatják, hogy egyre növekszik a cégek humáneröforrás-fejlesztési hajlandósága. Az elmúlt 10 év alatt az éves képzési napok száma munkavállalóként átlagban 2,45 nappal növekedett, miközben a képzésre fordított költséghányad a bérköltség arányában közel 0,5 százalékkal emelkedett. A képzések, tréningek hatékonyságáról a szervezetek alig fele készít értékelést, leginkább képzési célok megvalósulását vizsgálva és reakcióértékelést használva, miközben a befektetés-megtérülés (ROI) használata elenyésző. A hazai gyakorlatról, tendenciákról azonban nem áll rendelkezésre releváns információ. Ezért indítottuk el a "Tréningek és képzések hatékonysága Magyarország 2016" címü online kérdőíves felmérést a Grow Szervezetfejlesztési Tanácsadó Zrt. kezdeményezésére és támogatásával. A kutatás 2016 harmadik és negyedik negyedévében a Budapesti Kereskedelmi és Iparkamara, valamint a Humán Szakemberek Országos Szövetsége (HSZOSZ) szakmai támogatásával zajlott.

Az adatok összegyüjtésénél populációnak, a Magyarországon müködő önálló vállalatokat és intézményeket tekintettük (Babbie, 2001). Általában a HR-részlegeket kerestük meg, a kisebb szervezeteknél ennek hiánya esetén az elsőszámú vezető vagy annak közeli munkatársa(i) volt(ak) a célszemély(ek). Kutatásunk nem követte a véletlen mintavétel módszerét. Helyette kombinált módon választottuk ki a megkeresett szervezeteket. Ezt a módszert a kutatásmódszertanban szakértői vagy hozzáférés-alapú mintavételnek (Szokolszky, 2004) tekintik. Hasonló kutatási módszert követnek az üzleti életben azok a tanácsadó cégek is, amelyek egy adott ágazatra vagy a gazdaság egészére próbálnak meg különböző vezetési és szervezési kérdésekre tendenciákat meghatározni, vagy elörejelzéseket adni.

A korábbi szervezés és vezetési kutatásainkból ${ }^{3}$ rendelkezésünkre állt egy közel 4.000 szervezet adatait tartalmazó címlista, továbbá az egyszerűen elérhető alanyok módszerével (Babbie, 2001) a Budapesti Kereskedelmi és Iparkamara, az Országos Humánmenedzsment Egyesület (OHE), a Humán Szakemberek Országos Szövetsége (HSZOSZ) és a levelezős hallgatóink közremüködésével próbáltuk kutatási felhívásunkat eljuttatni az érintettekhez. Ilyen módon számításaink szerint közel 5.000 szervezethez jutott el a felhívásunk. Ez a szervezeti kör összetettségében és komplexitásában jóval sokrétübbnek tekinthető, mint egy egyszerü „fogd, ahol éred és találod” minta.

A vizsgálatban alkalmazott kérdőív leíró jellegü volt, minden esetben objektív adatokra építettünk. A kérdőívben a statisztikai elemzések megkönnyítése érdekében legtöbb esetben zárt kérdéseket alkalmaztunk. A vizsgált témaköröket nagymértékben lefedö, előre megfogalmazott válaszkategóriák közül a legjellemzőbbek megjelölését kértük a válaszadóktól. A felmérésben alkalmazott kérdőív a következő három fő részből áll:

- személyzetfejlesztés jellemzése,

- képzések-tréningek értékelése,

- válaszadó szervezetek és a válaszadó személyek jellemzői.

Kisebb részben személyes adatfelvételezéssel - itt elsősorban azokra a levelező tagozatos hallgatóinkra támaszkodtunk, akik valamely szervezetben aktív munkavállalóként vannak jelen - és nagyobb részben elektronikus módon gyüjtöttük össze a válaszokat. Kérdöívünk önkitöltős volt, és egy szervezettől értelemszerűen egy kérdőívet gyűjtöttünk be. A válaszadói kör meghatározása során törekedtünk arra, hogy azok ítéljék meg az egyes kérdéseket, akik releváns információval rendelkezhetnek a témával kapcsolatban. Ezt utólag ellenőriztük a válaszadó által megadott munka/feladatkör mentén. A felmérést 2016. III. negyedévben hajtottuk végre.

A jelzett módon összegyüjtött adatokat egy és többváltozós statisztikai módszerekkel elemeztük, és értékeltük a megfogalmazott hipotéziseink igaz vagy hamis voltát.

Figyelembe véve az eddigi vizsgálatokat és tapasztalatokat az alábbi hipotéziseket fogalmaztuk meg:

- H1: A közszférában müködő szervezetek nagyobb aránya készít képzési-fejlesztési tervet, mint a profitorientált cégek.

- H2: A nagyvállalatok átlagosan több képzési órát fordítanak a munkavállalókra, mint a kis- és középvállalkozások.

- H3: A nagyvállalatok esetében hangsúlyosabbak a költségigényesebb képzési formák, mint a KKV-knál.

- H4: A szervezetek többsége a képzésen résztvevők elégedettségét, a programmal kapcsolatos véleményét méri fel.

Kutatási hipotéziseink megfogalmazásánál elsősorban a már említett Cranet-kutatás utolsó két felmérésének eredményeiből indultunk ki. Ezek azt mutatják, hogy Közép-Kelet-Európa szervezetei a képzésekre fordított figyelemben, azok fontosságában lépést tartanak a gazdaságilag fejlett országokkal (Cranet, 2011, 2017; Karoliny - Poór, 2013; Kovács - Poór, 2017). A képzések fontosságának két indikátorát megvizsgálva, a napok számával mért évi átlagos képzési időben, bár lényeges különbségek

\footnotetext{
2 Magyarországi egyetemek (Pécsi Tudományegyetem és a Szent István Egyetem) 2004, illetve 2011 óta tagjai az 1989 óta létező CRANET (The Cranfield Network on International Human Resource Management) nonprofit nemzetközi HR-kutatóhálózatnak. A cikkben már jelzett következő három időszakban vettünk részt a CRANET-kutatásban: 2004-2005, 2008-2010, 2015-2016.

3 A Menedzsment és HR-kutató Központ 2008 óta végez évente 4-6 országos szintü, a vállalati és az intézményi menedzsment témában primer kutatást, társadalomtudományi módszerekkel.
} 
vannak a vizsgált különböző országok, illetve országcsoportok között, régiónk mind a menedzserek, mind a szakalkalmazottak esetében az élmezőnyben van $(7,2$, illetve 7,4 nap, míg a régiónkon kívül 7,6, illetve 8,2 nap az utolsó felmérésben). Ugyanakkor az adminisztratív és fizikai dolgozók esetében már nagyobb lemaradást mutatnak a régió szervezetei (5,4 vs. 7,3 nap). Globálisan a szervezeti méret nem befolyásolja számottevően az egy főre jutó képzési napok számát, egyedül az adminisztratív/fizikai dolgozók kategóriájában van jelentősebb különbség: az 1000 fö feletti szervezetek az utolsó felmérés szerint kb. 1,5 nappal többet szánnak e munkavállalói kategória képzésére, mint a kisebbek, és ez náluk körülbelül megegyezik a menedzserek képzésére fordított idővel. A közép-kelet-európai régió szervezeteinél markánsabb különbségek vannak: meglepő módon a legnagyobb, 5000 fő feletti szervezetekben a legalacsonyabb mind a menedzserek $(6,5)$, mind a szakalkalmazottak $(5,4)$ esetében az egy före jutó képzési napok száma, míg a legkisebbek (250 fö alatt) nincsenek lemaradásban a többiekhez képest, sőt a régiós átlagnál még jobbak is (7,6,8, illetve 5,8 nap). A képzés fontosságának további lényeges indikátora a képzési költség. Ebben a tekintetben a régiók közötti különbségek nem meghatározóak, Közép-Kelet-Európára az összes vizsgált régió átlagához közeli értékek jellemzőek. A szervezetek döntő többségében van képzési költségkeret, globálisan mindkét felmérésben 96\%, Közép-Kelet-Európában 92\%, illetve $95 \%$. Mindkét időszakban globálisan a cégek valamivel több, mint a fele 1-2\%-os, és közel 30\%-a 3-5\%-os képzési költségkerettel rendelkezik, 5\%-nál nagyobb képzési költségkeret mindkét időszakban a cégek 18\%-ára jellemző. A régiós értékek ezekhez hasonlóak, de kicsit eltolódva az alacsonyabb kategóriák irányába.

A 2016-os felmérés alapján a közép-kelet-európai régióban a szervezetek közel 60\%-ának van képzés-fejlesztési stratégiája, e régión kívül ez az arány valamivel magasabb, a szervezetek 2/3-tartozik közéjük. A képzésekre vonatkozó igényfelmérést a globális minta válaszadó szervezeteinek 2/3-ában végeznek, ezzel közel megegyezik a közép-keleteurópai régió értéke is. Míg azonban régiónkban közel megegyezik a privát- és közszférához tartozó szervezetek aránya, addig a globális mintában és a régión kívüli országokban is a közszférában valamivel magasabb az igényfelmérést végzők aránya ${ }^{4}$. A képzések szisztematikus értékelése a 2016-os felmérésben a globális minta szervezeteinek valamivel több, mint a felére jellemző, és ez az előző felméréshez képest némi emelkedést mutat. A KKE régióban is a globális mintáéhoz nagyon hasonló arányokat tapasztalhatunk, és hasonló tendencia érvényesül abban a tekintetben is, hogy a szisztematikus hatékonyság értékelés sokkal inkább jellemző a privátszférában, mint a közszférában (globálisan 56\%, illetve 45\%, KKE 54\% és 42\% 2016-ban).

Azokban a szervezetekben, ahol foglalkoznak a képzések szisztematikus értékelésével, ennek módszerei közül mindkét időszakban a képzési és fejlesztési tervben kitüzött célok elérése, a közvetlenül a képzés utáni reakcióértékelés és a vezetőktől és munkavállalóktól kapott informális visszajelzés a leginkább használatos. Az utolsó felmérés- ben ezeket a globális minta szervezeteinek 2/3-ában alkalmazzák, régiónkban az alkalmazók valamivel 50\% feletti aránya ettől valamelyest elmarad. A befektetés megtérülésével alig foglalkoznak a szervezetek (a globális mintában 19\%), és az összes közül ez a legkevésbé használatos módszer. Míg azonban az USA-ban és az Egyesült Királyságban ennél jóval nagyobb arányban, kb. a szervezetek egyharmadában alkalmazzák a ROI-t, addig régiónkban mindössze a szervezetek 14\%-a él ezzel a lehetőséggel. A munkateljesítmény mérése sem túlságosan népszerü egyik vizsgált országcsoportban sem: a globális mintában a vizsgált szervezetek körülbelül egyharmadánál fordul elő, míg régiónkban körülbelül egynegyedénél. Mindebből láthatjuk, hogy a képzések hatékonyságának mérésében a számszerüsíthető, kvantitatív adatokon alapuló eszközök a szervezetek döntő többségénél egyáltalán nincsenek jelen, nemcsak régiónkban, hanem globális viszonylatban sem.

\section{A magyarországi felmérés}

\section{Minta}

A kiküldött kérdőívvel összesen 643 szervezetet értünk el. Az adatbázis rendszerezését és az adatok ellenőrzését követően összesen 412 szervezet válaszait elemeztük. Fontos megjegyeznünk, hogy nem mindegyik kérdést (változó) válaszolták meg teljes körüen. Ebből kifolyólag egyes változók vizsgálata során alacsonyabb elemszámmal dolgoztunk, mint 412. Az 2. ábrán a szektorok szerinti megoszlást láthatjuk. A diagram alapján megállapíthatjuk, hogy a válaszadó szervezetek jelentős arányban, 67,8\%-ban a magánszektorból kerültek ki. 24,5\% a közszférában müködő szervezetek aránya. Legalacsonyabb százalékban, 3,1\% és $4,6 \%$ a nonprofit és a vegyes tulajdonú szervezetek vettek részt a kutatásban.

\section{A résztvevők megoszlása (\%)}

2. ábra

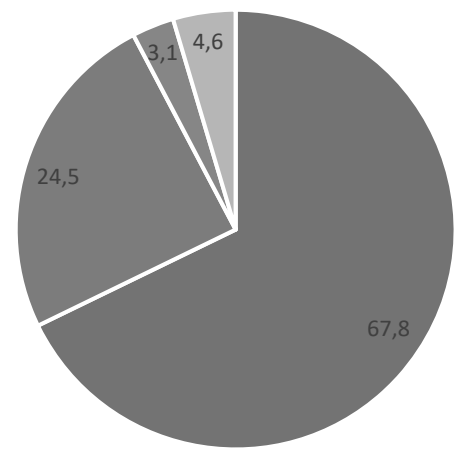

- Magánszektor "Közszféra =Nonprofit =Vegyes (köz- és magánszektor)

Forrás: a szerzők saját szerkesztése

\section{A képzés és az oktatás jellemzői}

Jelen tanulmányban elsőként azt vizsgáltuk, hogy a mintába kerülő szervezetek felmérik-e a munkavállalók képzéséhez, fejlesztéséhez kapcsolódó igényeket. A 3. ábra 
alapján elmondhatjuk, hogy mindegyik szektor esetében a vizsgált szervezetek többsége végez igényfelmérést.

A kérdöívben nem kérdeztünk rá az igényfelmérés jellegére. A válaszok vonatkozhatnak a munkavállalók személyes igényeire, egyes szervezeti egységek, divíziók igényeire, és a stratégiai döntéshozók elvárásaira is.

3. ábra

\section{Tréningszükségletre vonatkozó igényfelmérést végzők aránya (\%)}

Készül igényfelmérés a munkavállalók képzéséhez, fejlesztéséhez az Önök szervezetében?

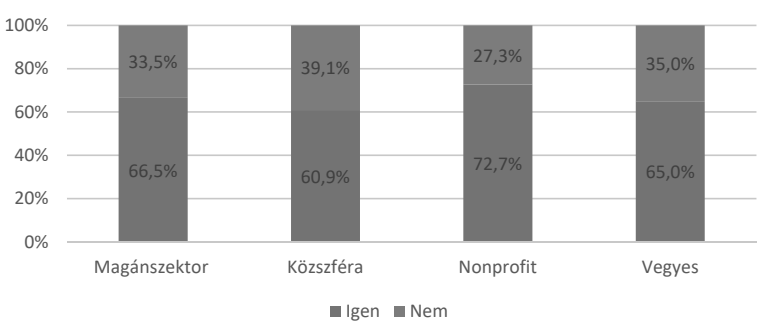

Forrás: a szerzők saját szerkesztése

A kiküldött kérdőívben megkérdeztük a válaszadóktól azt, hogy készítenek-e képzési tervet? A kérdésre kapott válaszokat a 4. ábrán ábrázoltuk. Az eredmények alapján megállapítható, hogy a vizsgált szervezetek többségénél készül képzési terv. Legnagyobb arányban a közszférában jellemző a tervek készítése. Az állami szféra tervezési gyakorlata azzal is magyarázható, hogy az ilyen szervezeteknek minden év első napjaiban jelezniük kell a képzési igényeiket. A forprofit szervezetek esetében feltételezhető az is, hogy bizonyos esetekben a képzési programok adhoc jelleggel vannak jelen és a humánfejlesztés kevésbé képezi részét a stratégiának.

\section{Képzési tervet készítők aránya (\%)}

4. ábra

Készül az Önök szervezetére vonatkozóan képzési terv?

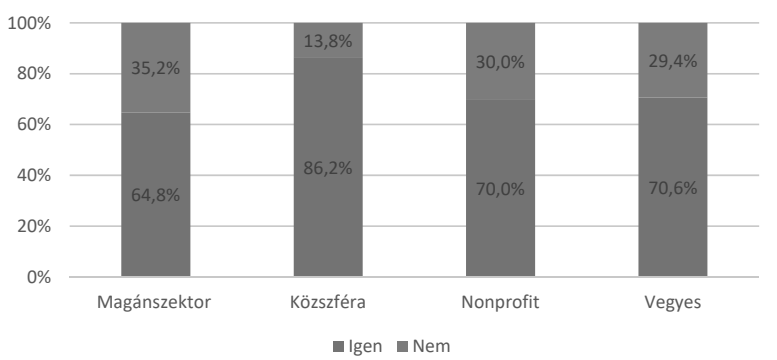

Forrás: a szerzők saját szerkesztése

Az 1. táblázatban összefoglaltuk, hogy milyen képzések valósultak meg az elmúlt két évben a megkérdezett szervezeteknél. Az adatok alapján elmondható, hogy a legtöbb szervezetnél a munkahelyen, a munkához kapcsolódó betanítási folyamat, a csapatépítő tréning, valamint konferencia, szeminárium és előadás valósult meg. Az újonnan érkező munkavállalók betanítása és bevezetése elengedhetetlen folyamat. Várható volt tehát, hogy a vizsgált szervezetek magas arányban említik az ez irányú képzést. Meglepő azonban, hogy gyakran említették a csapatépítő tréninget is. Itt megjegyeznénk azonban, hogy a köznyelv-

A képzések és tréningek típusai

1. táblázat

\begin{tabular}{|c|c|c|c|c|c|c|}
\hline \multicolumn{2}{|l|}{ Típusok } & Magánszektor & Közszféra & Nonprofit & $\begin{array}{l}\text { Vegyes (köz- és } \\
\text { magánszektor) }\end{array}$ & Össz. \\
\hline \multirow{2}{*}{ Konferencia, szeminárium, előadás } & $\mathrm{N}$ & 208 & 82 & 11 & 15 & 316 \\
\hline & $\%$ & $77 \%$ & $83 \%$ & $100 \%$ & $88 \%$ & $79 \%$ \\
\hline \multirow{2}{*}{ Képesítést nem nyújtó szakmai tanfolyam } & $\mathrm{N}$ & 171 & 71 & 10 & 12 & 264 \\
\hline & $\%$ & $66 \%$ & $77 \%$ & $83 \%$ & $67 \%$ & $69 \%$ \\
\hline \multirow{2}{*}{ Csapatépítő tréning } & $\mathrm{N}$ & 246 & 64 & 10 & 13 & 333 \\
\hline & $\%$ & $89 \%$ & $67 \%$ & $77 \%$ & $72 \%$ & $82 \%$ \\
\hline \multirow{2}{*}{ Nyelvtanfolyam } & $\mathrm{N}$ & 154 & 38 & 5 & 7 & 204 \\
\hline & $\%$ & $56 \%$ & $40 \%$ & $39 \%$ & $39 \%$ & $51 \%$ \\
\hline \multirow{2}{*}{ OKJ-s szakmát biztosító képzés } & $\mathrm{N}$ & 50 & 17 & 3 & 8 & 78 \\
\hline & $\%$ & $19 \%$ & $18 \%$ & $23 \%$ & $50 \%$ & $20 \%$ \\
\hline \multirow{2}{*}{ Számítógépes (IKT) tanfolyam } & $\mathrm{N}$ & 76 & 36 & 4 & 11 & 127 \\
\hline & $\%$ & $30 \%$ & $41 \%$ & $33 \%$ & $69 \%$ & $35 \%$ \\
\hline \multirow{2}{*}{ Önismereti, képesség, kompetenciafejlesztő tréning } & $\mathrm{N}$ & 162 & 43 & 10 & 12 & 227 \\
\hline & $\%$ & $62 \%$ & $48 \%$ & $83 \%$ & $67 \%$ & $60 \%$ \\
\hline \multirow{2}{*}{ Állami képesítést nem nyújtó szakképző tanfolyam } & $\mathrm{N}$ & 26 & 23 & 0 & 8 & 57 \\
\hline & $\%$ & $11 \%$ & $27 \%$ & $0 \%$ & $47 \%$ & $16 \%$ \\
\hline \multirow{2}{*}{ Munkahelyen munkához kapcsolódó betanítási folyamat } & $\mathrm{N}$ & 251 & 76 & 12 & 12 & 351 \\
\hline & $\%$ & $91 \%$ & $78 \%$ & $92 \%$ & $63 \%$ & $87 \%$ \\
\hline \multirow{2}{*}{ Hatósági képzések } & $\mathrm{N}$ & 77 & 35 & 2 & 4 & 118 \\
\hline & $\%$ & $30 \%$ & $42 \%$ & $18 \%$ & $24 \%$ & $32 \%$ \\
\hline
\end{tabular}


ben a „csapaépítés” nem feltétlenül fedi le azt a fejlesztési technikát, amit a csoportkohézió erösítése végett végzünk. A gyakorlat azt mutatja, hogy a munkahelyen kívül eltöltött, bármilyen közös programra csapatépítő jelleggel tekintetnek a cégek/szervezetek. Szintén gyakran fordul elő elem a konferencia és előadás. Népszerüsége talán azzal magyarázható, hogy egyre több konferencialehetőség ingyenes, rövid és több munkavállaló tud egyszerre részt venni rajta.

A továbbiakban (2. táblázat) kiemelten a KKV-k és a nagyvállalatok képzési gyakorlatait hasonlítottuk össze. Az adatok alapján szembetünő, hogy mindegyik képzési forma a megkérdezett szervezetek közül a nagyvállalatok esetében valósult meg gyakrabban. Ez leginkább azzal magyarázható, hogy a nagyvállalatok ,tőkeerősségükből” fakadóan nagyobb képzési kerettel tudnak gazdálkodni. Érdekes azonban az, hogy az eredmények alapján nem tudunk KKV-specifikus képzési formát megragadni. Látható, hogy a két forprofit szervezeti kategória, hasonló tendencia mentén jelölte az egyes képzési formákat.

2. táblázat

\section{Képzések/tréningek típusai a vállalati méret függvényében}

\begin{tabular}{|c|c|c|c|}
\hline \multicolumn{2}{|l|}{$\begin{array}{l}\text { Az elmúlt } 2 \text { évben az Önök } \\
\text { szervezeténél milyen típusú képzések/ } \\
\text { tréningek valósultak meg? }\end{array}$} & \multirow{2}{*}{$\begin{array}{c}\mathrm{KKV} \\
116 \\
\end{array}$} & \multirow{2}{*}{$\begin{array}{c}\text { Nagyvál- } \\
\text { lalatok }\end{array}$} \\
\hline \multirow{2}{*}{ Konferencia, szeminárium, előadás } & $\mathrm{N}$ & & \\
\hline & $\%$ & $70,70 \%$ & $86,30 \%$ \\
\hline \multirow{2}{*}{$\begin{array}{l}\text { Képesítést nem nyújtó szakmai } \\
\text { tanfolyam }\end{array}$} & $\mathrm{N}$ & 91 & 77 \\
\hline & $\%$ & $58,70 \%$ & $83,70 \%$ \\
\hline \multirow{2}{*}{ Csapatépítő tréning } & $\mathrm{N}$ & 136 & 99 \\
\hline & $\%$ & $82,40 \%$ & $99,00 \%$ \\
\hline \multirow{2}{*}{ Nyelvtanfolyam } & $\mathrm{N}$ & 74 & 75 \\
\hline & $\%$ & $44,80 \%$ & $76,50 \%$ \\
\hline \multirow{2}{*}{ OKJ-s szakmát biztosító képzés } & $\mathrm{N}$ & 25 & 22 \\
\hline & $\%$ & $15,30 \%$ & $26,20 \%$ \\
\hline \multirow{2}{*}{ Számítógépes (IKT) tanfolyam } & $\mathrm{N}$ & 36 & 39 \\
\hline & $\%$ & $22,80 \%$ & $47,60 \%$ \\
\hline \multirow{2}{*}{$\begin{array}{c}\text { Önismereti, képesség/ } \\
\text { kompetenciafejlesztő tréning }\end{array}$} & $\mathrm{N}$ & 83 & 72 \\
\hline & $\%$ & $53,20 \%$ & $79,10 \%$ \\
\hline \multirow{2}{*}{$\begin{array}{l}\text { Állami képesítést nem nyújtó } \\
\text { szakképző tanfolyam }\end{array}$} & $\mathrm{N}$ & 17 & 9 \\
\hline & $\%$ & $11,20 \%$ & $11,80 \%$ \\
\hline \multirow{2}{*}{$\begin{array}{l}\text { Munkahelyen munkához } \\
\text { kapcsolódó betanítási folyamat }\end{array}$} & $\mathrm{N}$ & 146 & 96 \\
\hline & $\%$ & $90,10 \%$ & $96,00 \%$ \\
\hline \multirow{2}{*}{ Hatósági képzések } & $\mathrm{N}$ & 41 & 30 \\
\hline & $\%$ & $25,90 \%$ & $35,70 \%$ \\
\hline
\end{tabular}

Forrás: a szerzők saját szerkesztése

Az 5. ábra a képzési napok alakulását mutatja az egyes alkalmazotti kategóriákban. Független mintás t-próba segítségével vizsgáltuk, hogy az egyes kategória (KKV - Nagyvállalat) átlagok mutatnak-e statisztikailag is igazolható eltérést. A Levene-teszt egy esetben sem volt szignifikáns. Az adatok alkalmasnak bizonyultak a t-próba elvégzésére. Az eredmények alapján szignfikáns eltérés mutatkozott a vezetőkre ( $\mathrm{t}=-3,088, \mathrm{df}=247, \mathrm{p}=0,002)$, a szellemi (szak) alkalmazottakra $(\mathrm{t}=-2,772, \mathrm{df}=246, \mathrm{p}=0,006)$ és az iro- dai/adminisztratív dolgozókra $(\mathrm{t}=-2,341, \mathrm{df}=239, \mathrm{p}=0,02)$ jutó képzési napok esetében a KKV-k és a nagyvállalatok között. A fizikai dolgozókra jutó képzési napok statisztikailag nem különböznek igazolhatóan. Ha megvizsgáljuk a 4. ábrát megállapíthatjuk, azt is, hogy a vizsgált minta esetében minél magasabban helyezkedik el egy pozíció a szervezeti hierarchiában annál több képzési nap jut rá.

Az eredmény magyarázható azzal, hogy a ,tudásigényes" munkakörökre jobban fókuszálnak a szervezetek. Más megközelítésben feltételezhető az is, hogy magasabb szintü munkakörökben a képzési cél inkább a „puhább” kompetenciák fejlesztése, amihez olyan módszerekre van szükség, melyek átlagosan több időt vesznek igénybe.

5. ábra

\section{A képzési napok alakulása munkaköri kategóriák és vállalati méret függvényében}

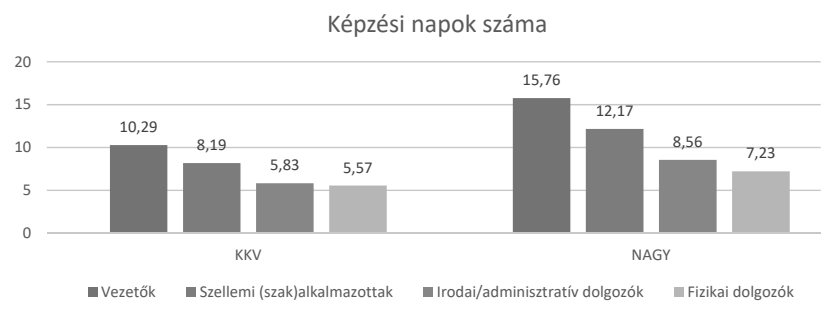

Forrás: a szerzők saját szerkesztése

A 6. ábrán ábrázoltuk a „Készül szisztematikus értékelés a képzési/tréning programjaik hatékonyságáról az Önök szervezetében?" kérdésre kapott válaszokat. Az eredmények alapján elmondhatjuk, hogy a szisztematikus értékelés inkább a nagyvállalati gyakorlatra jellemző.

\section{A képzés/tréninghatékonyság értékelése (\%)}

6. ábra

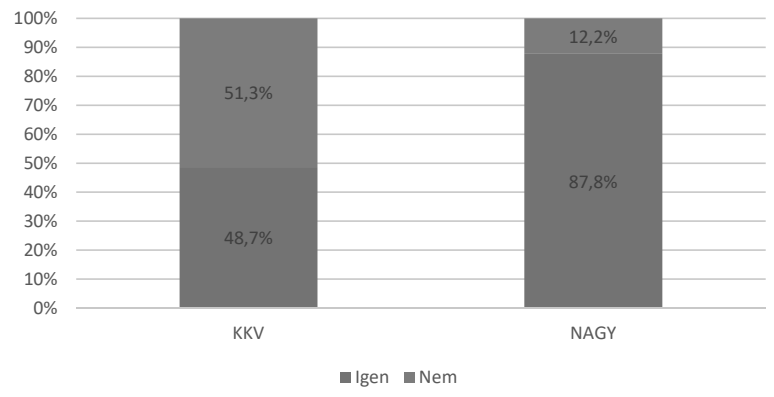

Forrás: a szerzők saját szerkesztése

Megvizsgáltuk, hogy azok a szervezetek, akik végeznek értékelést, milyen módszereket alkalmaznak. Az eredmények alapján elmondható, hogy a közvetlenül a képzés utáni reakcióértékelés, az informális visszajelzés, valamint az elégedettség felmérés a KKV-nál és a nagyvállalatoknál is gyakori. A befektetés-megtérülés vizsgálata, valamint a tudásfelmérés kevésbé elterjedt és a szervezeti kategóriákon belül is inkább a nagyvállalati gyakorlatra jellemző. A tendenciákból kitünik, hogy a szervezetek főként azokat 
az értékelési technikákat alkalmazzák, melyek viszonylag egyszerüen elvégezhetők. Az összetettebb elemzéseket, magasszintű szaktudást igénylő értékelési módszerek alkalmazása ritkább. (3. táblázat)

3. táblázat

\section{Az értékelési módszerek alkalmazása}

\begin{tabular}{|c|c|c|c|c|c|}
\hline $\begin{array}{l}\text { Értékelési mód- } \\
\text { szerek }\end{array}$ & & $\begin{array}{l}\text { Min- } \\
\text { dig }\end{array}$ & $\begin{array}{l}\text { Gyak- } \\
\text { ran }\end{array}$ & Néha & Soha \\
\hline \multirow{2}{*}{$\begin{array}{l}\text { Közvetlenül a kép- } \\
\text { zés utáni reakcióér- } \\
\text { tékelés }\end{array}$} & KKV & $68 \%$ & $17 \%$ & $10 \%$ & $6 \%$ \\
\hline & NAGY & $68 \%$ & $26 \%$ & $4 \%$ & $3 \%$ \\
\hline \multirow{2}{*}{$\begin{array}{l}\text { Képzés elötti és } \\
\text { közvetlenül utána } \\
\text { mért munkateljesít- } \\
\text { mény }\end{array}$} & KKV & $9 \%$ & $25 \%$ & $30 \%$ & $36 \%$ \\
\hline & NAGY & $7 \%$ & $13 \%$ & $41 \%$ & $39 \%$ \\
\hline \multirow{2}{*}{$\begin{array}{l}\text { Képzés előtti és a } \\
\text { néhány hónappal } \\
\text { később mért mun- } \\
\text { kateljesítmény }\end{array}$} & KKV & $12 \%$ & $13 \%$ & $34 \%$ & $40 \%$ \\
\hline & NAGY & $0 \%$ & $24 \%$ & $41 \%$ & $34 \%$ \\
\hline \multirow{2}{*}{$\begin{array}{l}\text { A közvetlen veze- } \\
\text { tőktől kapott infor- } \\
\text { mális visszajelzés }\end{array}$} & $\mathrm{KKV}$ & $36 \%$ & $35 \%$ & $21 \%$ & $8 \%$ \\
\hline & NAGY & $33 \%$ & $43 \%$ & $19 \%$ & $5 \%$ \\
\hline \multirow{2}{*}{$\begin{array}{l}\text { A munkavállalóktól } \\
\text { származó informá- } \\
\text { lis visszajelzés }\end{array}$} & $\mathrm{KKV}$ & $32 \%$ & $38 \%$ & $19 \%$ & $10 \%$ \\
\hline & NAGY & $19 \%$ & $50 \%$ & $28 \%$ & $3 \%$ \\
\hline \multirow{2}{*}{$\begin{array}{l}\text { Befektetés-megté- } \\
\text { rülés }\end{array}$} & KKV & $15 \%$ & $17 \%$ & $20 \%$ & $48 \%$ \\
\hline & NAGY & $4 \%$ & $22 \%$ & $33 \%$ & $41 \%$ \\
\hline \multirow{2}{*}{ Elégedettségmérés } & KKV & $40 \%$ & $28 \%$ & $24 \%$ & $8 \%$ \\
\hline & NAGY & $47 \%$ & $32 \%$ & $14 \%$ & $7 \%$ \\
\hline \multirow{2}{*}{ Tudásmérés } & KKV & $14 \%$ & $24 \%$ & $36 \%$ & $26 \%$ \\
\hline & NAGY & $12 \%$ & $41 \%$ & $28 \%$ & $20 \%$ \\
\hline \multirow{2}{*}{ Magatartásváltozás } & KKV & $5 \%$ & $16 \%$ & $33 \%$ & $47 \%$ \\
\hline & NAGY & $2 \%$ & $23 \%$ & $31 \%$ & $44 \%$ \\
\hline \multirow{2}{*}{$\begin{array}{l}\text { Online, same-time } \\
\text { adatgyüjtés (pl. } \\
\text { applikáció) }\end{array}$} & KKV & $2 \%$ & $0 \%$ & $15 \%$ & $83 \%$ \\
\hline & NAGY & $5 \%$ & $19 \%$ & $16 \%$ & $60 \%$ \\
\hline
\end{tabular}

Forrás: a szerzők saját szerkesztése

\section{Következtetések}

Az első hipotézisünkben azt állítottuk, hogy a közszférában müködő szervezetek nagyobb aránya készít képzési-fejlesztési tervet, mint a profitorientált cégek. Ha szektortól függetlenül vizsgáljuk a kérdést, az adatok alapján következtetni tudunk arra, hogy a vizsgált szervezetek többségénél készül képzési terv. Az eredmények mégis azt mutatják, hogy az állami szektorban müködő szervezetek képviselői nagyobb arányban jelezték, hogy készülnek képzési tervek. A felállított hipotézist igazoltnak véljük. A közszféra, állami szféra tervezési gyakorlata azzal magyarázható, hogy az állami szervezeteknek minden év első napjaiban jelezniük kell a képzési igényeiket. A képzési tervek relatív elmaradását a forprofit szervezetek esetében magyarázhatjuk azzal, hogy sok esetben a különbözö képzési programok nem rendszeres, előre megtervezett módon valósulnak meg. Ez a gyakorlat nagyban jellemzi a kisebb szervezeteket.

A második hipotézisünkben feltételeztük, hogy a nagyvállalatok átlagosan több képzési órát fordítanak a munkavállalókra, mint a kis- és középvállalkozások. A statisztikai próbákkal rámutattunk arra, hogy szignifikáns eltérés van a vezetőkre jutó képzési napok esetében, a KKV-k és a nagyvállalatok között. A fizikai dolgozókra jutó képzési napok statisztikailag nem különböznek igazolhatóan. Az eredmények alapján következtetni tudunk arra, hogy minél magasabb szinten helyezkedik el egy pozíció a szervezeti hierarchiában annál több képzési napot fordítanak e munkaköröket betöltő munkavállalókra. A hipotézisünket elfogadjuk. Az eredmény egyfelől magyarázható azzal, hogy a kulcsmunkakörökre nagyobb hangsúlyt fektetnek a szervezetek, másfelöl azzal is, hogy magasabb szintü munkakörökben az olyan kompetenciák fejlesztése a cél, amelyekhez a módszereket tekintve több idő szükséges.

A harmadik hipotézisünkben feltételeztük, hogy a nagyvállalatok esetében hangsúlyosabbak a költségigényesebb képzési formák, mint a KKV-nál. Az eredmények alapján leginkább arra tudunk következtetni, hogy a felsorolt képzési formákat minden esetben nagyvállalatok alkalmazzák gyakrabban. A hipotézisünket nem tudjuk egyértelmüen elfogadni. Az adatokból arra következtethetünk, hogy nincs KKV-specifikus képzési metódus. Az eredményekből kitünik, hogy a KKV-k és a nagyvállalatok is, hasonló tendencia mentén jelölték az egyes képzési formákat. A nagyvállalatoknál megfigyelhető, hogy mindegyik képzési formát nagyobb gyakorisággal jelölték meg, amit magyarázhatunk azzal, hogy nagyobb képzési kerettel tudnak gazdálkodni. Máshonnan megközelítve feltételezhető az is, hogy a nagyvállalatokat jobban jellemzi a humántőkére fókuszáló szervezeti kultúra.

Végezetül a negyedik hipotézisünkben állítottuk, hogy a szervezetek többsége a képzésen résztvevők elégedettségét, a programmal kapcsolatos véleményét méri fel. A kutatás eredményei mutatják a szervezeti képzések-tréningek kapcsán alkalmazott értékelési módszerek előfordulási eseteit, mely alapján megállapítható, hogy a KKV-k és a nagyvállalatok vonatkozásában is több mint 90\%-ban alkalmazott a „közvetlenül a képzés utáni reakcióértékelés, a közvetlen vezetőtől kapott informális visszajelzés", „a munkavállalóktól kapott informális visszajelzés”, az „elégedettségmérés”. A ,tudásmérés” a KKV-k esetében 74 , a nagyvállalatok esetében $80 \%$-ban van jelen. A hipotézist igazoltnak tekintjük. A, ,képzés előtti és közvetlenül utána mért munkateljesítmény”, valamint a „képzés előtti és a néhány hónappal később mért munkateljesítmény" mint értékelési módszer előfordulása és alkalmazása már csak a válaszadók közel kétharmadánál jellemző. Az alkalmazott értékelési módszerek sorát a magatartásváltozás és az online, same-time adatgyüjtés zárja, jelentős százalékos visszaeséssel. Ezen adatok is utalhatnak arra, hogy a képzési költségek növekedését jelenti a korrekt és szakmailag megalapozott visszamérés, értékelés, ami miatt a vállalatok - amennyiben az értékelés, mint egy választható elem szerepel a képzési program tervezésekor - ezen elem elhagyásával tudnak költséget/kiadást csökkenteni.

Mindezek alapján tehát kijelenthető, hogy régiónk szervezeteinek jelentős hányada felismerte a képzések és 
fejlesztések fontosságát, kellő figyelmet és anyagi erőforrásokat fordítva rá, ugyanakkor még mindig viszonylag népes azoknak a tábora is, akik nem vagy nem megfelelö mértékben áldoznak erre. Nem vitatható, hogy a képzések jelentős költségtényezőt jelentenek, éppen ezért gazdasági problémák esetén a cégek gyakran ezen a területen próbálják a költségeiket csökkenteni. Hosszabb távon azonban ez egyáltalán nem kifizetődő, hiszen így a szervezet tudásvagyona, humántőkéje nem gyarapodik, hanem apad; ezért fontos lenne annak felismerése és felismertetése, hogy a szervezetben felhalmozott tudás, a humántőke erodálódása előbb-utóbb gazdasági eredményekben is mérhető.

\section{A kutatás korlátai, jövőbeli tervek}

A kutatás rávilágít arra, hogy a szervezetek elenyésző számban élnek a képzés - tréning hatékonyságértékelés valamely teljes körü módszerével. Az okok között említik meg, hogy e tevékenység nem része a szervezeti kultúrának amellett, hogy hiányolják a megfelelően kidolgozott módszertant is. A hatékonyságértékelés módszere a szakirodalom által jól kőrvonalazott, ugyanakkor igen gyakran szükséges lehet az adott szervezet adott képzésére szabott adaptációja, mely jelentős költségnövelö tényezö egy képzési csomagban.

A hazai és nemzetközi trendek összevetéséhez a 41 ország kutatóit tömörítő nonprofit HR-kutató hálózat, a Cranet áll rendelkezésre. Ahhoz, hogy hazánkban is a szakma képviseletében hangsúlyozni tudjuk a HRM kritikus sikertényezői szerepét a szervezeti müködésben, fontos nemzetközi összehasonlító kutatáshoz kapcsolódnunk. Ebben a folyamatban ugyanis élö kapcsolat van a kutatók között, ahol a kulturális tudás, kritikus felvetések, szakértelem, team intellektus, erős hatással van a kutatási folyamatra.

Kelet-Közép-Európában, így hazánkban is a felzárkózás jegyében szükséges figyelemmel kísérni a nemzetközi trendeket. Jelen téma vizsgálatánál is jól látszik a lemaradás és egyben a fejlődési szükséglet is, magyar viszonylatban.

A jövőben is, egy nemzetközi kutatáshoz kapcsolódó hazai kutatás kibővítése, aktualizálása - a HRM területén - hasznos információkat szolgáltat a szervezeti gyakorlat és kutatói tevékenységet folytatók számára.

\section{Felhasznált irodalom}

Ambrus T. - Lengyel L. (2006): Humán controlling számítások. Budapest: Complex Kiadó Jogi és Tartalomszolgáltató Kft.

Babbie, E. (2001): A társadalomtudományi kutatás gyakorlata. Budapest: Balassi Kiadó

Bálint J. (2001): Minőség - Tanuljuk, tanítsuk, valósítsuk meg és fejlesszük tovább. Budapest: Terc Kft.

Bartscher, T. - Nissen, R. (2017): Personalmanagement. Hallbergmoos: Pearson

Berde Cs. - Móré M. (2014): A munkavállalói tudás hasznosításának új lehetősége felsőoktatási keretek között. Vezetéstudomány, 45. (11.), pp. 44-54.
Bokor A. -Csillag S. -Szilas R. - Bácsi K. -Szöts-Kováts K. (2007): Emberi erőforrás menedzsment. Budapest: Aula Kiadó

Bramley, P. - Kitson, B. (1994): Evaluating Training against Business Criteria. Journal of European IndustrialTraining, 18.(1.), pp.10-14,

Brewster, C. - Morley, M. - Buciuniene, I. (2010): The reality of human resource management in Central and Eastern Europe. Baltic Journal of Management, (5.), pp. 145-155.

Brewster, C. (1999): Strategic human resource management: the value of different paradigms. Management International Review, 39. (3.), pp. 45-64.

Brewster, C. (2007): A European perspective on HRM. European Journal of International Management, 1. (3.), pp.239-259.

Cranet (2006): International Executive Report 2005, Cranet Survey on Comparative Human Resource Management. Cranfield: Cranet-Cranfield University

Cranet (2011): International Executive Report 2011, Cranet Survey on Comparative Human Resource Management. Cranfield: Cranet-Cranfield University

Cranet (2017): International Executive Report 2017, Cranet Survey on Comparative Human Resource Management. Cranfield: Cranet-Cranfield University

Csillag, S. -Toarniczky, A. - Primecz, H. (2018): Dolgoznánk, ha hagynátok... Megváltozott munkaképességű emberek és a HR-rendszerek. Vezetéstudomány, 49 (6). pp. 33-45. DOI https://doi.org/10.14267

Dewey, J. (1938): Experience and Education. New York: Macmillan

Dobos Á. (2009): Az interaktív felnőttképzés eredményessége a tréningmódszer tükrében. Felnőttképzés, (2.)

Dolobáč, M. - Mura, L. - Švec, M. (2016): Personnel management and the new system of dual education in Slovak Republic. Actual Problems of Economics, 181. (7.), pp. 282-289.

Dunne, S. - Lunn, C. - Kirwan, M. - Matthews, A. - Condell, $S$. (2015): Planning and selecting evaluation designs for leadership training: a toolkit for nursemanagers and educators. Journal of Professional Nursing: Official Journal of the American Association of Colleges of Nursing, 31, pp. 475-81.

Farjad, S. (2012): The Evaluation Effectiveness of Training Courses in University by Kirkpatrick Model. ProcediaSocial and Behavioral Sciences, (46.), pp. 2837 - 2841.

Ford, J. - Henderson, R. - O'hare, D. (2014): The effects of Crew Resource Management (CRM) training on flightattendants' safety attitudes. Journal of Safety Research, 48, pp. 49-56.

Gilmore, S. - Williams, S. (2013): Human Resource Management.(2nd. ed.) Oxford: Oxford University Press

Goldstein, I. L. - Ford, K. (2002): Training in Organizations: Needs assessment, Development and Evaluation. Belmont: Wadsworth

Gomez-Mejia, R.L. - Balkin, B.B. - Cardy, L. R. (2016): Managing Human Resources. Boston: Pearson

Gösi Zs. (2007): Mérlegen az ember. 88. sz. Műhelytanulmány. Budapest: Corvinus Egyetem Vállalatgazdaságtan Intézet 
Gregor, A. - Pallai K. (2016): Kormánytisztviselői integritás tréningek hatásosságának elemzése. Pro Publico Bono, (2.), pp. 4-25.

Héra G. - Ligeti Gy. (2005): Módszertan - bevezetés a társadalmi jelenségek kutatásába. Budapest: Osiris Kiadó

Hoós, J. (2000): Globalisation, Multinational Corporation and Economics. Budapest: Akadémiai Kiadó

Juhász E. (2009): Tréningek tervezése és szervezése. In: Henczi L. (szerk): Felnőttoktató. Budapest: Nemzeti Tankönyvkiadó, pp.328-332.

Karoliny M-né - Farkas F. - Poór J. (2010): Az emberi erőforrás menedzselés magyarországi változásai (két egymást követő Cranet felmérés eredményei alapján). Competitio, 9. (2.), pp. 92-110.

Karoliny M-né - Poór J. (2013): A HR-gyakorlatok alakulásának összehasonlító vizsgálata a világ négy régiójában, közép-kelet-európai sajátosságokat keresve. Competitio, 12. (2.), pp.20-38.

Kirkpatrick, D. (1998): Evaluating Training Programs: The Four Levels. San Francisco: Berrett-Koehler

Kotler, P. - Caslione, J.A. (2011): Kaotika. Budapest: Manager Kiadó

Kovács, I. É. - Poór, J. (2017): Quo vadis HRM? HR gyakorlatok alakulása - Közép-Kelet-Európa nemzetközi összehasonlításban. In: Farkas A. F.Orosz S. - Rudnák I. (szerk.): Tudományterületek a multikulturalitás kontextusában (Branches of Sciences in MulticulturalContext). Gödöllő: Szent István Egyetem Kiadó, pp.172-189.

Kovács I. É. - Karoliny M-né (2015): A HR tanácsadás alakulása a válság előtt és a válság alatta a globális Cranet kutatás tükrében. In: Innováció - Növekedés - Fenntarthatóság. A VII. Országos Tanácsadói Konferencia tanulmánykötete. Budapesti Kereskedelmi és Iparkamara Gazdasági Szolgáltatások Tagozat, XX. Tanácsadó Osztály. 2014. október 30., pp.118-123.

KSH (2014): Felnőttoktatás, felnőttképzés. Budapest: Központi Statisztikai Hivatal

Légrádiné Lakner Sz. (2006): Tréningmódszer a felsőoktatásban. Tudásmenedzsment, 7. (1.), pp.6066.

Martín-Alcázar, F. - Romero-Fernandez, P. - SánchezGardey, G. (2005): Strategic human resource management: integrating the universalistic, contingent, configurational and contextual perspectives. The International Journal of Human Resource Management, 11. (5), pp.633-659.

Matiscsákné Lizák Marianna (szerk.) (2012): Emberi erőforrás gazdálkodás. Budapest, Complex Kiadó

Moldovan, L. (2016): Training Outcome Evaluation Model. Procedia Technology, 22(1), pp.1184- 1190.

Mollahoseini, A. - Farjad, S. (2012): Assessment Effectiveness on the job training in Higher Education. Procedia - Social and Behavioral Sciences (47.), pp.1310 $-1314$.

Munkahelyi képzések (2015) (előzetes adatok) http://www. ksh.hu/docs/hun/xftp/stattukor/mhelykepzesek15.pdf. (Letöltés dátuma:2017.07. 12.)
Olšovská, A. - Mura, L. - Švec, M. (2016): Personnel management in Slovakia: An explanation of the latent issues. Polish Journal of Management Studies, 13, (2), pp. 110-120.

Phillips, J. J. (2003): Return on Investment in Training and Performance Improvement Programs. Burlington: Butterworth-Heinemann

Poór J. (2009): Nemzetközi emberi erőforrás menedzsment. Budapest: Complex Kiadó

Poór J. (2013): Nemzetköziesedés és globalizáció az emberi erőforrás menedzsmentben. Budapest: Complex Kiadó

Praslova L. (2010): Adaptation of Kirkpatrick's four level model of training criteria to assessment of learning outcomes and program evaluation in higher education. Educational Assessment, Evaluation and Accountability, 22. (3), pp. 215-225.

Price, A. (2015 ): Human Resource Management. (4th ed.) Hampshire: South Western Cengage Learning

Rajeev, P. - Madan, M.S. - Jayarajan, K. (2009): Revisiting Kirkpatrick's model - an evaluation of an academic training course. Current Science, 96. (2), pp.272-276.

Roos, M. - Kadmon, M. - Kirschfink, M. - Koch, E. Junger, J. - Strittmatter-Haubold, V. - Steiner, T. (2014): Developing medical educators - a mixed method evaluation of a teaching education program. Medical Education Online, 27.

Samad, A. - Kazi, A. K. - Raheem, M. (2014): Critical Success Factors of Knowledge Management Systems Implementation. KASBIT Business Journal Vol. 7. No. 2., pp. 64-78.

Sánchez, A. A. - Marín, G.S. - Morales, A.M. (2015): The mediating effect of strategic human resource practices on knowledge management and firm performance. In: Revista Europea de Dirección y Economía de la Empresa, 24.(3.), pp. 138-148. http://www.sciencedirect. com/science/article/pii/S1019683815000190

Schultz, T. W. (1993): The Economic Importance of Human Capital in Modernization. Education Economics, 1. (1.) pp 13-19.

Shankar, J. (2007): A novel 360-degree evaluation. Proceeding of the 6th European Conference on E-learning, pp.573-581.

Szalai P. (2009): A tréning, mint a hatékonyság növelésének eszköze a HR-es kezében. Humánpolitikai Szemle, 20. (2), pp. 3-11

Szokolszky Á. (2004): A kutatómunka a pszichológiában. Budapest: Osiris Kiadó

Tarcsi Á. - Molnár B. (2014): Vállalatirányítási rendszerek gazdaságinformatikai megközelítésben. Budapest: ELTE Informatikai Kar

Torrington, D. - Hall, L. - Taylor, S. - Atkinson, C. (2014): Human Resource Management. Harlow: Pearson

Tót É. (2002): A nem formális tanulás elismerése-szemlélet és módszerek. Szakképzési Szemle, 8. (2.), pp.178-194.

Vámosi Z. (2005): Humán erőforrás menedzsment. Budapest: LSI Oktatóközpont

Vaszari Tamás (2016): A vezetőképzések szerepe a gazdasági versenyképességben.Vezetéstudomány/ Budapest Management Review, 47 (7), pp. 54-63. 